\title{
MOBILE MEDIA COMMUNICATIONS' INFLUENCE UPON PURCHASE DECISIONS IN THE CASE OF ENT DRUGS FOR CHILDREN AND ON THE CHOICE OF DOCTORS
}

\author{
ANDREI BORANGIU ${ }^{1}$, DANIEL ADRIAN GÂRDAN ${ }^{2 *}$, IULIANA PETRONELA GÂRDAN ${ }^{2}$, \\ IACOB CĂTOIU ${ }^{3}$, VICTOR LORIN PURCĂREA ${ }^{4}$, THEODOR PURCĂREA ${ }^{5}$
}

1 "Carol Davila” University of Medicine and Pharmacy, 8 Eroii Sanitari Boulevard, 050474, Bucharest, Romania

2 "Spiru Haret" University, Faculty of Economic Sciences, 46G Fabricii Street, 060821, Bucharest, Romania

${ }^{3}$ Bucharest University of Economic Studies, Faculty of Marketing, 6 Romană Square, 010374, Bucharest, Romania

4 "Carol Davila" University of Medicine and Pharmacy, 37 Dionisie Lupu Street, 020021, Bucharest, Romania

${ }^{5}$ Romanian-American University, 1 B Expoziției Boulevard, 012101, Bucharest, Romania

*corresponding author: danielgardan@gmail.com

\begin{abstract}
The present article is aimed at answering the fundamental hypothesis that the buying decision for ENT (Ear Nose Throat) children prescribed drugs and the choice of doctors are influenced to a great extent by the parents' use of mobile media communications. Authors have done a qualitative exploratory research as an in-depth interview with parents having children between 0 and 10 years of age, who are actively under an ENT treatment scheme. The results are showing that frequent users of mobile media communication software perceive the use of the software as being very easy and at hand, having the availability to communicate with the ENT doctor. The treatments prescribed by the doctor are validated before other suggestions received from the acquaintances, family etc. and alternative drugs, from the point of view of the active substances, are sought in a differentiated manner, especially if prescribed drugs are seen as having undesirable side effects on children.
\end{abstract}

\section{Rezumat}

Prezentul articol își propune să ofere un răspuns avansării ipotezei potrivit căreia deciziile de cumpărare a medicamentelor din sfera ORL (OtoRinoLaringologie) pentru copii și alegerea medicilor specialiști sunt influențate în mare măsură de utilizarea softurilor de comunicații media-mobilă de către părinți. În acest sens, autorii au realizat o cercetare exploratorie calitativă sub forma unui interviu cu părinții care au copii între 0 și 10 ani și care au avut sau au o schemă de tratament ORL. Rezultatele denotă faptul că utilizatorii frecvenți ai acestor softuri de comunicație media mobilă percep utilizarea softului ca fiind foarte facilă și la îndemână, având disponibilitatea și pentru comunicarea cu medicul ORL. Tratamentele prescrise de către medic sunt validate înaintea altor sugestii primite de la cunoștințe, familie iar medicamentele alternative din punct de vedere a substanțelor active sunt căutate în mod diferențiat, în special în cazul în care medicamentele prescrise sunt interpretate ca având efecte secundare nedorite asupra copiilor.

Keywords: ENT-prescribed drugs, purchase decision, mobile media communication, influencers

\section{Introduction}

The problem represented by the way patients make decisions regarding a certain treatment or the actual interaction with the doctor is an extremely interesting, current and complex one. As we speak about the Otolaryngology medical field, the buying decisional process for ENT (Ear Nose Throat) specific drugs or the consumption behaviour related to healthcare services is very specific and nowadays patients are using a variety of information sources for decision. The increased access of individuals to electronic sources of information in the medical field, as well, increased the sensitivity to the importance of the availability of medical information. In a research made on 578 Dutch people, the results show that there was a strong relationship between the degree of satisfaction and the amount of medical information received about the drugs and treatment scheme [20]. The development of e-health solutions has led to the idea that this new blending between ITC technology and medicine can replace the traditional way of delivering healthcare. The need to implement e-health practices is more and more taken into consideration by governments, health professionals and research institutions in the field of health in both developed and developing countries [9].

A sustainable communication effort using marketing specific channels implies integrated communication with all the categories of stakeholders, the use of ICT within this field being undoubtedly the main way to obtain a valuable approach on this matter [25]. In the context of these new developments, the problem of medical care quality has a growing importance. 
According to their own level of culture, people tend to change their buying and consumption behaviour for a diversity of products or services [8].

Perceptions regarding the medical importance of a certain condition contribute in the same time to the importance of the medical act quality perceptions. Research suggests that the quality within healthcare setting is composed of two fundamental dimensions: technical quality and functional quality. In most cases patients are unable to asses correctly the technical quality that is reflecting the accuracy of diagnosis, competence of the professionals, expertise. The functional quality is evaluated by patients mainly with the help of tangible elements like: equipment, appearance of employees, interior design, deco signage, etc. [10, 26]. The field of Otolaryngology comprise a range of situations in which patients are assessing the quality of interventions. From this point of view, we can assume that within different aspects that can be used as discussion topics between parents with children having ENT problems, quality of healthcare services, and especially quality of the relationship with the doctor, is a major one. From a medical point of view, paediatric ENT affections have a major importance within the general ENT pathology. It includes head and neck infections, tumoural pathology, respiratory and vocal fold problems, ear affections and surgical treatment of a multitude of problems (e.g. postintubational laryngo-tracheal stenoses, tympanic membrane perforations, adenoid hypertrophy). In the same time, these medical problems are very important from the point of view of the parents, as they are preventing children from fully integrating socially and from having a normal life [11]. Because of the major implications that the ENT affections can have, it is indicated for parents to go with the children to the paediatrician as soon as the first signs appear. If the paediatrician recommends the ENT specific examination, the parents should take immediate action and go to the ENT specialist, because, frequently, diseases that are presenting like a simple cold with an ear pain, could evolve towards a major medical condition like acute otitis media, sometimes with severe complications [12]. For children specific medical issues, parents are holding the position of decision makers in terms of drugs consumption and buying behaviour, communication with doctors and healthcare facilities usage. From the point of view of children's influence upon parents' decisions, research shows that children's age positively influences the parents' behaviour, namely, as the age of the children increases, they make an attempt to influence the purchase decisions for a larger set of products [13].

In the specific setting of children ENT conditions, young mothers are having the most important role in the communication with doctors, the use of the recommended treatment scheme etc. The degree of decision and types of decision made by mothers regarding healthcare issues is different depending on geographical and cultural context. They are also influenced by socio-economic factors such as: education, household structure, proximity to family, marital status, number of children [15].

Young people are manifesting nowadays different levels of digital literacy and the propensity to use on a large scale electronic means of communication blended with modern telecommunication devices. People are willing to share different kinds of information through social media channels. Within a research made on Romanian consumers it has been highlighted that $30 \%$ of them are having their email address shown on their public social media profile $[17,30]$.

The concept of digital literacy in terms of health related issues (eHealth literacy) is referring to media competence, IT knowledge and a certain basic scientific knowledge level. This also suggests that a mHealth intervention involving text messaging may be potentially scalable and sustainable across a larger group of people that are having access to mobile phones. This kind of intervention was targeting initially the adherence of individuals to a certain medication but has evolved over time and is capable in present days to address a wide range of topics in response to participants' needs and preferences for support [3].

Research into the field has shown also that there can be established a direct link between mobile phone use and strong social interaction [21].

The real "revolution" of the mobile telephone is that all people become reachable on individual bases. Everyone can be contacted anytime and connected with the others; leading to a social behaviour characterized by coordination and shared activities most of the time. Using mobile media communication applications (e.g. WhatsApp), individuals have an instrument to bypass many traditional communication barriers. Different studies are describing WhatsApp as a low-cost and fast technology that allows the clinical communications, can enhance learning process for patients, and contribute to the improvement of patient care without losing their privacy [19]. Other evidence suggest that usage of WhatsApp application for example within the context of dermatology healthcare services has numerous advantages like: easy integration within the daily routine of healthcare clinics, no additional costs for internet, easy usage without a special training for the doctors, possibility to actually make healthcare consultation for patients, patient triage, etc. [31].

In the same time, the use of the mobile media communication tool has permitted a better care coordination among different specialties, like otolaryngology, ophthalmology, oromaxilofacial surgery, general surgery, plastic surgery and oncology that can be linked with the dermatology team to coordinate care for patients with complex head and neck tumours. High quality photos transmitted over the application give surgeons the possibility to asses different situations 
that are requiring interventions and schedule patients accordingly for surgery or for other referral from different surgical specialty if is the case [23].

Recent studies are showing that determinants for the use of WhatsApp in healthcare setting are having an individual nature from the point of view of healthcare professional use - doctors are using it because of its perceived usefulness, meantime some organizational factors can play a secondary role, still mediated by individuals [6].

The topic of parents' decision on drugs administrated to their children is a very delicate one, as the importance of the health condition of the child is transferred to the parents.

In a research made in Saudi Arabia, the results have shown that only $1.3 \%$ of parents followed instructions regarding antibiotic usage and 50\% did not receive any advice from their doctor regarding the use of antibiotics [1]. In general, parents are having a low awareness regarding the need to use antibiotics especially in developing countries, a fact related with the low medical literacy and the poor implication of authorities [2, 28].

Parents base their opinions on personal past experience and want reassurance and supplementary advice regarding antibiotic use for their children treatment [4].

A common issue is represented by the fact that low education and poor information regarding correct use of drugs, especially antibiotics, is leading to a misuse of these drugs and the phenomena of antibiotics resistance [27].

It is also proven that, in order to have a certain prolonged effect, national programs regarding the awareness of parents for the antibiotic use of children treatment has to be done repeatedly, and for a long period [18].

\section{Materials and Methods}

The research was conceived as an in-depth interview type research aimed at investigating and exploring the perceptions of young parents regarding the importance of mobile media communication software usage for the choice of ENT doctors and buying decisions for the ENT prescribed drugs.

The in-depth interview research is used mainly as an exploratory type research that reveals intentions, opinions, perceptions or attitudes on a specific topic, being classified as clinic type interview, untargeted interview or semi structured type interview [5].

The present research falls into the category of semi structured type interview as the authors need to analyse specific answers for specific topics.

As objectives the research assumed: knowing the degree of familiarity with media communication software like WhatsApp, Viber etc., determining the ENT conditions communication need expressed by the respondents, exploring the content of mobile media software communication, characterization of ENT doctor choice decision, determining the importance degree associated with doctor's recommended ENT drugs buying decision, measuring the mobile media communication software usage influence upon the ENT doctor choice and ENT drugs buying decision.

Participants were carefully selected from among young parents having children between 0 - 10 years of age with ENT affections and an active treatment scheme, based on a filter type questionnaire. There has been a final number of 58 interviews recorded audio-video and transcribed for analysis.

Table I

Characteristics of the interview respondents

\begin{tabular}{|c|c|}
\hline \multicolumn{1}{|c|}{ Interview respondents } & $\begin{array}{c}\text { Total } \\
\mathrm{n}(\%)\end{array}$ \\
\hline Gender & \\
\hline Male & $5(8.6)$ \\
\hline Female & $53(91.4)$ \\
\hline Age (years) & $2(3.4)$ \\
\hline $18-25$ & $36(62.1)$ \\
\hline $26-35$ & $18(31.1)$ \\
\hline $36-50$ & $2(3.4)$ \\
\hline $51-65$ & 0 \\
\hline$>65$ & $36(62.1)$ \\
\hline Number of children & $21(36.2)$ \\
\hline 1 & $1(1.7)$ \\
\hline $2-4$ & \\
\hline$>4$ &
\end{tabular}

In order to interpret properly the information obtained, authors have made a content type analysis and a thematic analysis on the transcripts. Content analysis has been used for many types of text analysis within research in a clinical and social context [22].

Qualitative content analysis and thematic analysis are classified under the qualitative descriptive design. They are sets of techniques used to analyse textual data and elucidate the theme. Their key characteristic is the systematic process of coding, examining of meaning and provision of a description of the social reality through the creation of a theme. The "theme" is the main product of data analysis that yields practical results in the field of study.

There are many similarities between qualitative content analysis and thematic analysis, for instance cutting across data, philosophical background, attention to both description and interpretation in data analysis, consideration of context of data, and searching for themes [29].

\section{Results and Discussion}

The results are showing a strong involvement of the respondents regarding the topics of discussion approached within the conversation guide. The involvement has in the same time a rational and an emotional dimension as the topics are referring to health problems of the 
respondents' children, their perceptions and actions towards this delicate subject. As a general observation, the vocabulary used is specific for the selected respondents - mainly young mothers having children with ENT disorders. The terms used are describing the attitudes, convictions, habits and perception regarding the interaction with other parents, with the doctors.

The final responses are referring to 58 discussions recorded and transcribed accordingly. In the following we are presenting the most important ideas analysed from the point of view of the main hypothesis of the research: the use of mobile media communication software has a direct effect upon decision buying process of ENT drugs and subsequently upon the ENT paediatrician choice.
The topic referring to the "purchase decision for ENT prescribed drugs for children - the importance of decisions" is highlighting a series of ideas such as: the majority of respondents think that there is no need for a correlation between what is recommended by the ENT paediatrician and by friends, in the same time the doctor's opinion is considered the most important one. Some of the respondents consider that the recommendation of the ENT specialist is very important because there are drugs that can cause dependency. In the same time there is highlighted the idea that respondents do not feel the need for WhatsApp group members or friends to validate their own choices regarding the drugs used.

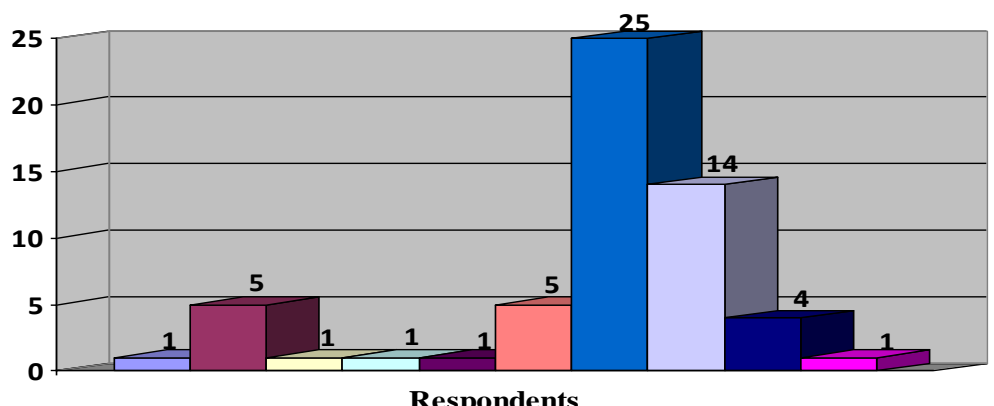

Respondents

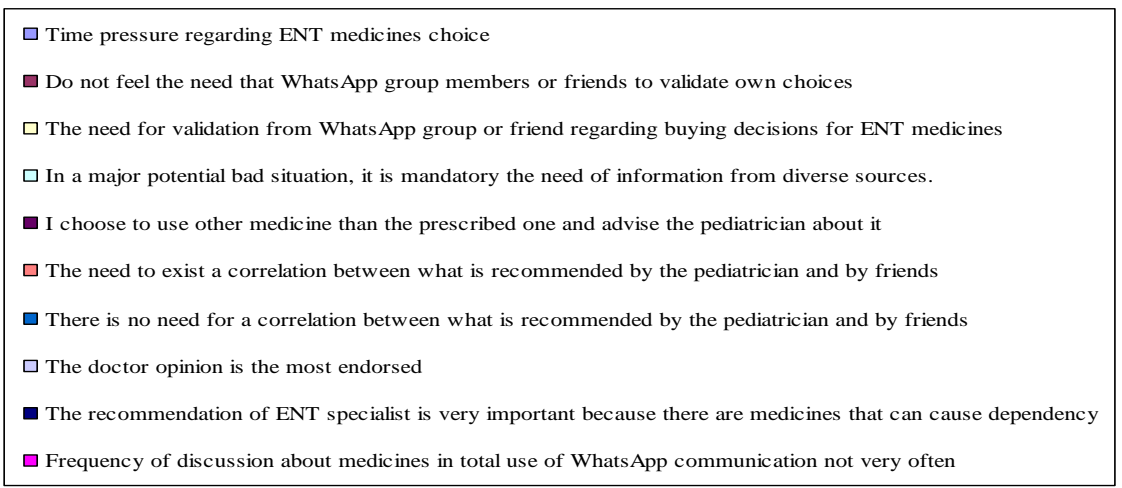

Figure 1.

Respondents' opinions about influence of communication with mobile media upon decisions regarding ENT prescribed drugs for children $(n=58)$

The topic referring to the "the degree of influence of the decisions regarding the choice of the ENT paediatrician based on the communication with the software dedicated to the mobile media communication" has brought to light some interesting ideas: the communication with mobile media software (e.g. WhatsApp), does not imply a change at the level of intention to choose a specific ENT paediatrician specialist or another. This opinion was shared by the majority of respondents, only two of them affirming that they could change their mind regarding the doctors choice due to the information received through the use of mobile media software. A very isolated opinion was sustaining the idea that the choice of the ENT doctor is finally made through classic visits to the medical office, and there is a need for direct experimentation of the relationship with the doctor. Answers to this topic confirm the fact that majority of users have already integrated communication with mobile media software into their usual everyday perception upon different phenomena and actions, implying decision over healthcare problems or related ones. That is because as other opinions corresponding to other topics are showing, communication with software is seeing as being a natural one, capable to help people to transmit and receive in a personalized way and an intimate manner essential information about their choices, decisions, desires and motivations. 

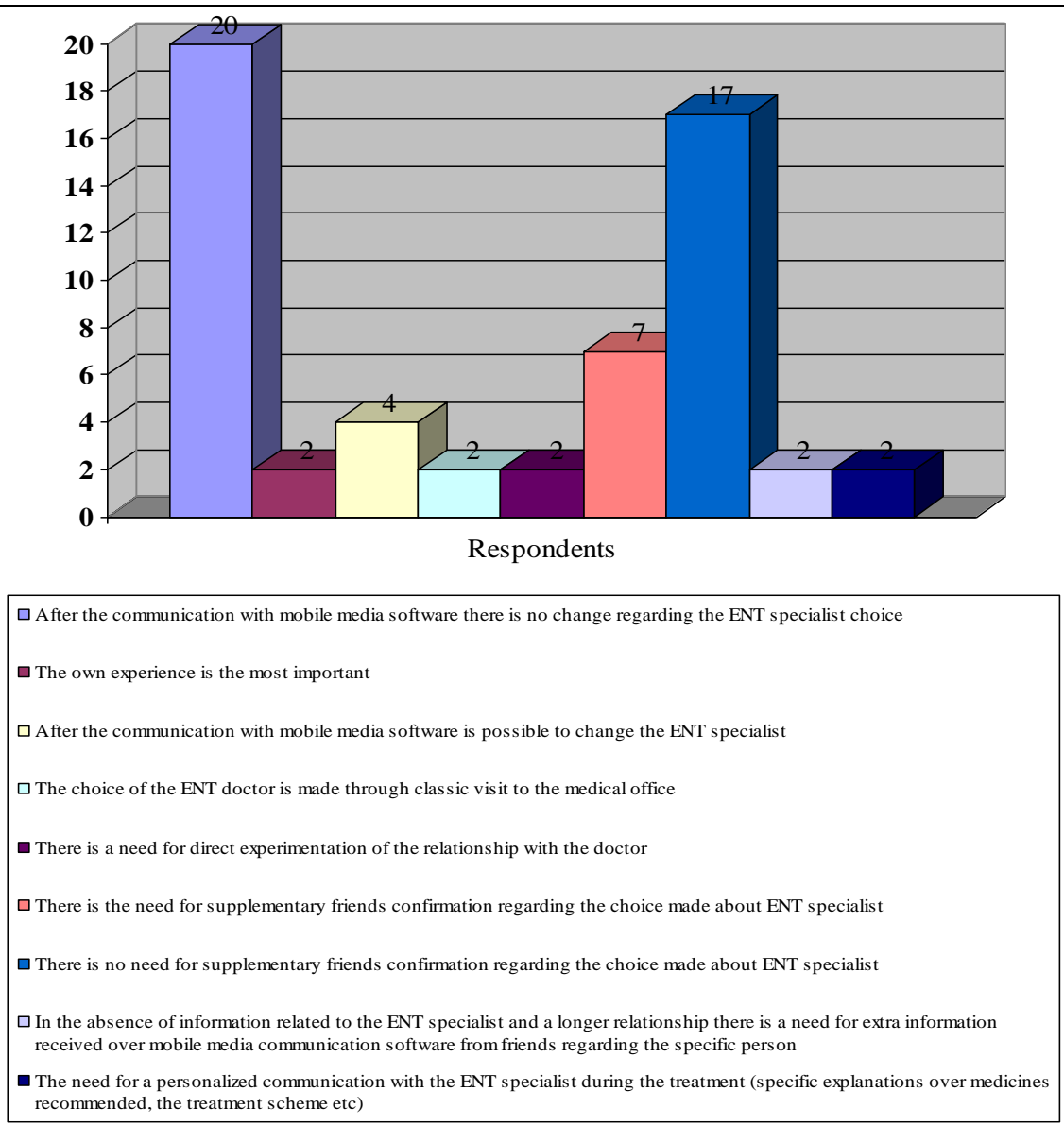

Figure 2.

Respondents' opinions about influence of communication with mobile media upon decisions regarding the choice of the ENT paediatrician $(n=58)$

Another item was related to the fact that the majority of respondents appreciate that there is no need for supplementary friends' confirmation regarding the choice made about an ENT specialist. The response is showing a strong degree of confidence in their own decision-making capacity, and the high level of involvement within the process of choosing an ENT specialist for the children's treatment.

Another topic of discussion relevant for the main hypothesis advanced within our research is referring to the "degree of influence of the purchasing decision for the medicines addressing ENT disorders based on communication with mobile media software". This topic has shown that the majority of respondents perceive the recommendation of ENT paediatrician as being the most important one, despite the different opinions met over the WhatsApp discussions. Only seven cases consider that it was useful to renounce to the ENT paediatrician recommendation after the communication with others on WhatsApp. Respondents also consider that it is not necessary, as a purchasing habit, to buy alternative drugs instead of the prescribed ones. Among the answers received to this topic of discussion there is a singular opinion very interesting from the point of view of the perception expressed: the information received on WhatsApp is changing the perception of the individual about a specific medicine, but not the buying decision on it. Other answers highlight the fact that there was a need to change a particular medicine after the discussion with the pharmacist and to share information with others after the discussion with the paediatrician. There are singular opinions, but they are showing the diversity of opinions among the respondents, due to different cultural backgrounds, consumption experiences so far and perceptions upon the relationship patient - doctor.

The final topic permitted to respondents to share their opinions about different issues regarding the general use of the software. One of the most important from the point of view of the main hypothesis was that a lot of people that are actually using WhatsApp as a day by day mobile media communication software can be influenced after they participate in different group discussions regarding their choices about ENT drugs or ENT specialists. The majority of respondents consider that the main possible reason for this kind of behaviour is the lack of self-confidence followed by the negative past experiences with some ENT specialists before. 


\section{Conclusions}

The results of the research show that our main hypothesis is partially confirmed, as it can be seen that the influence of mobile media software communication upon respondents was complex and special, having also subtle meanings. One important conclusion based on our research is that the majority of users have already integrated communication with mobile media software into their usual everyday perception upon different phenomena and actions, implying decision over healthcare problems or related ones. Communication with software is seeing as being a natural one, capable to help people to transmit and receive in a personalized way and an intimate manner essential information about their choices, decisions, desires and motivations. These results are in line with other findings from scientific literature. In a research conducted in 2017 , authors studied the way in which different factors are influencing consumers' intentions to seek health information in mobile social media websites. The findings are showing the complexity of the way in which people are developing a certain behaviour related with health information seeking on mobile social media sites and perception upon their own health risk and health self-efficacy.

Authors identified four type of social support offered by the social media websites (tangible support, appraisal support, emotional support and esteem support). Tangible support and appraisal support significantly influence perceived risk. In the same time emotional support and esteem support are significantly influence health self-efficacy. The research demonstrates the fact that today's healthcare services consumers are integrating social media and mobile social media as tools within their health issues related behaviour [7].

A research made on 378 respondents is showing that nowadays consumers are developing loyalty towards social mobile applications software, based on satisfaction, tight connection with others, and hedonic motivation to use the apps.

In the same time, satisfaction and usage habits are mediating the relationship between perceived usefulness and intention to use the applications in the future.

If we try to extend the results of the above study to the medical field, it becomes obvious that usage of mobile healthcare related apps is influenced by the same factors - with the remark that hedonic motivation to use is replaced by a utilitarian motivation maybe [14]. Another important conclusion of our research shows that there is no need for supplementary friends' confirmation regarding the choice made about a paediatric ENT specialist. The response is showing a strong degree of confidence in their own decisionmaking capacity, and the high level of involvement within the process of choosing an ENT specialist for the children's treatment. The majority of respondents perceive the recommendation of the ENT paediatrician as being the most important one, despite the different opinions met over the WhatsApp discussions. The answers received for the last discussion topic of the interview guide are showing the respondents' perception regarding the possibility that individuals that are actually using WhatsApp as a day by day mobile media communication software can be influenced after they participate in different group discussions regarding their choices about ENT drugs or ENT specialists. The majority of respondents consider that the main possible reason for this kind of behaviour is the lack of self-confidence followed by the negative past experiences with some ENT specialists before.

Future directions of research should use our exploratory findings type information as a starting point for quantitative type research that should give a clearer answer from a statistical point of view. Answers can comprise the relationship between variables that are characterizing decisional buying process for ENT type drugs and variables that are showing perception on mobile media communication software influence.

In present days the propensity to using social media and sharing of information within the otolaryngology medical field is a reality [24]. Still, in the same time social media is embraced as a tool by the individuals and still not by the institutions [32], which means that there are still more steps to be made in order to use at a full scale the advantages given by such technologies.

\section{Conflict of interest}

The authors declare no conflict of interest.

\section{References}

1. Al-Ayed MSZ, Parents' Knowledge, Attitudes and Practices on Antibiotic Use by Children. Saudi J Med Medical Sci., 2019; 7(2): 93-99.

2. Alsolmi MS, Mulla HH, Sindi STA, Nazer NWM, Almarzooq MMH, Alhamood MA, Alsadah ZH, Alqattan AA, Alharthi MSM, Alsadeq KMS, Awareness level of parents toward antibiotics those are prescribed to their children in Al-Dammam City. Indo Am J Pharmaceut Sci., 2018; 5(12): 15969-15972.

3. Aschbrenner KA, Naslund JA, Gill LE, Bartels SJ, Ben-Zeev D, A qualitative study of client-clinician text exchanges in a mobile health intervention for individuals with psychotic disorders and substance use. J Dual Diagnosis, 2016; 12(1): 63-71.

4. Bosley H, Henshall C, Appleton JV, Jackson D, A systematic review to explore influences on parental attitudes towards antibiotic prescribing in children. J Clin Nurs., 2018; 27(5-6): 892-905.

5. Cătoiu I, Teodorescu N, Consumers behaviour. $2^{\text {nd }}$ Edition, Uranus Publishing House. Bucharest, 2007 (available in Romanian).

6. De Benedictis A, Lettieri E, Masella C, Gastaldi L, Macchini G, Santu C, Tartaglini D, WhatsApp in hospital? An empirical investigation of individual and organizational determinants to use. PloS ONE, 2019; 14(1): $\mathrm{e} 0209873$ : 1-12. 
7. Deng Z, Liu S, Understanding consumer health information-seeking behavior from the perspective of the risk perception attitude framework and social support in mobile social media websites. Int J Med Inform., 2017; 105: 98-109.

8. Epuran G, Tescasiu B, Specific Euro-marketing elements in the single European market. A cultural approach. Bul Transilvania Univ Brașov. Economic Sci. Series V., 2015; 8(1): 47-52.

9. Furusa SS, Coleman A, Factors influencing e-health implementation by medical doctors in public hospitals in Zimbabwe. South Afr J Information Manag., 2018; 20(1): 1-9.

10. Gârdan IP, Gârdan DA, The GAP Model Applied to Dental Healthcare Services. In the Proceedings of the International Conference "Marketing-from Information to Decision". Babeș Bolyai Univ, ClujNapoca, 2014; 7: 107-126.

11. Gheorghe DC, Zamfir-Chiru-Anton A, Pathogenic discussions about pneumoccocal meningitis and possible involvement of the ENT specialist in the management of the disease. Ro J Med Pract., 2018; 13(4(61)): 289-292, (available in Romanian).

12. Gheorghe DC, Zamfir-Chiru-Anton A, Therapeutic Approach in Pediatric Tympanosclerosis: a Case Review, in Bertesteanu, SV; Grigore, R, (eds), National ent, head and neck surgery conference, may 17-20, Sibiu, 2017; 75-78.

13. Guneri B, Yurt O, Kaplan MD, Delen M, The Influence of Children on Family Purchasing Decisions in Turkey. As J Market., 2009; 3: 20-32.

14. Hsiao CH, Chang JJ, Tang KY, Exploring the influential factors in continuance usage of mobile social Apps: Satisfaction, habit, and customer value perspectives. Telematics and Informatics, 2016; 33(2): 342-355.

15. Ihler F, Canis $M$, The Role of the Internet for Healthcare Information in Otorhinolaryngology. LaryngoRhino-Otologie, 2019; 98(S 01): S290-S333.

16. Ionescu L, E-Government and Social Media as Effective Tools in Controlling Corruption in Public Administration. Econom Manag Financ Markets, 2016; 11(1): 66-72.

17. Ionescu L, Lăzăroiu $\mathrm{G}$, Şerban S, A theory of the availability and level of consumer protection in online and mobile payments for public economic services. Amfiteatru Economic, 2013; 15(34): 369-384.

18. Ivanovska V, Angelovska B, Van Dijk L, Zdravkovska M, Leufkens HG, Mantel-Teeuwisse AK, Change in parental knowledge, attitudes and practice of antibiotic use after a national intervention programme. Eur $J$ Public Health, 2018; 28(4): 724-729.

19. Kamel Boulos M, Giustini D, Wheeler S, Instagram and WhatsApp in health and healthcare: An overview. Future Internet, 2016; 8(3): 1-14.
20. Kooy MJ, Van Geffen EC, Heerdink ER, Van Dijk L, Bouvy ML, Patients' general satisfaction with telephone counseling by pharmacists and effects on satisfaction with information and beliefs about medicines: results from a cluster randomized trial. Patient Rduc Counsel., 2015; 98(6): 797-804.

21. Ling R, Children, youth, and mobile communication, J Children Media, 2007; 1(1): 60-67.

22. Macnamara JR, Media content analysis: Its uses, benefits and best practice methodology. Asia Pac Pub Relat J., 2005; 6(1): 1-34.

23. Mars M, Scott RE, WhatsApp in clinical practice: A literature review. Stud Health Tech Informat., 2016; 231: 82-90.

24. Oyewumi M, Lee J, Vescan A, Social media in otolaryngology-head and neck surgery. Ear, Nose \& Throat J., 2017; 96(9): 29-33.

25. Popescu IC, Dumitru I, Vegheş C, Kailani C, Marketing communication as a vector of the Romanian small businesses sustainable development. Amfiteatru Economic, 2013; 15(7): 671-686.

26. Purcărea VL, Gheorghe IR, Petrescu CM, The assessment of perceived service quality of public health care services in Romania using the SERVQUAL scale. Procedia Economics and Finance, 2013; 6: 573-585.

27. Rouusounides A, Papaevangelou V, Hadjipanayis A, Panagakou S, Theodoridou M, Syrogiannopoulos G, Hadjichristodoulou C, Descriptive study on parents' knowledge, attitudes and practices on antibiotic use and misuse in children with upper respiratory tract infections in Cyprus. Int J Environ Res Pub Health, 2011; 8(8): 3246-3262.

28. Sztankovszky LZ, Iorga M, Soponaru C, Antofie I, Issues about promoting drugs in Romania. Opinions of the pharmaceutical representatives. Farmacia, 2016; 64(3): 481-486

29. Vaismoradi M, Jones J, Turunen H, Snelgrove S, Theme development in qualitative content analysis and thematic analysis. J Nurs Educ Pract., 2016; 6(5): 100-110.

30. Vegheș $\mathrm{C}$, Developing the personal data protection in the European Union: A consumer-oriented approach the Romanian experience. Rev Business Inform Syst., 2008; 12(1): 63-74.

31. Williams V, Kovarik C, WhatsApp: An innovative tool for dermatology care in limited resource settings. Telemedicine and e-Health, 2018; 24(6): 464-468.

32. Xie DX, Dedmon MM, O'Connell BP, Yawn RJ, Haynes DS, Evaluation of social media presence of otolaryngology residency programs in the United States. JAMA Otolaryngology-Head\&Neck Surg., 2018; 144(9): 802-806. 